УДК 658. $511: 657.633$

Куичик П. О., kutsykpetro@gmail.com,ORCID ID:0000-0001-5795-9704, Researcher ID: G-9204-2019

д.е.н., проф., ректор, професор кафедри обліку, контролю, аналізу та оподаткування, Львівський торговельно-економічний університет, м. Львів

Воронко Р. М., rvoronko@ukr.net, ORCID ID: 0000-0003-3796-2556,

Researcher ID: F-8536-2019,

д.е.н., доч., завідувач кафедри обліку, контролю, аналізу та оподаткування, Львівський торговельноекономічний університет, м. Львів

Редченко К. I., redchenko@ukr.net, ORCIDID:0000-0001-8234-4074, Researcher ID: F-3039-2013, д.е.н., проф., професор кафедри обліку, контролю, аналізу та оподаткування, Львівський торговельно-економічний університет, м. Львів

Воронко О. С., oksanavoronko@i.ua,ORCID ID: 0000-0002-8235-611X,

Researcher ID: F-8553-2019,

к.е.н., дои., доцент кафедри обліку, контролю, аналізу та оподаткування, Львівський торговельноекономічний університет, м. Львів

\title{
АНАЛІТИЧНЕ ЗАБЕЗПЕЧЕННЯ УПРАВЛІННЯ ФОРМУВАННЯМ ФІНАНСОВИХ РЕЗУЛЬТАТІВ СУБ'ЄКТІВ БІЗНЕСУ
}

Анотація. Розглянуто важливість показників фінансових результатів для оцінювання ефективності діяльності суб'єктів господарювання. Економічний аналіз визначено як інструмент інформачійного забезпечення прийняття раціональних управлінських рімень. Визначено завдання аналізу фінансових результатів, спрямовані на виявлення факторів впливу на їх величину, надання пропозицій з мобілізації виявлених резервів щзоо поліпшення прибутковості діяльності та підвищення рентабельності. Акцентовано увагу на проблемних питаннях, які стосуються аналізу фінансових результатів та використання прибутку, зокрема інформаційної бази та методики його проведення. Економічний зміст фінансового результату встановлено як співставлення отриманих доходів з понесеними витратами звітного періоду, що спричиняє приріст або зменшення величини власного капіталу. Фінансовий результат характеризує підсумок діяльності суб'єкта бізнесу (прибуток або збиток) за певний період часу. Розкрито загальноекономічний, управлінський $і$ обліково-аналітичний аспекти тлумачення фінансових результатів. Встановлено, щзо фінансовий результат, який формується в управлінському обліку, зорієнтований на можливі варіанти прийняття рішень менеджерами різних рівнів, власниками, інвесторами чи кредиторами. Аналіз фінансових результатів повинен включати не тільки деталізоване оцінювання прочесу формування прибутку, але і його використання. Визначено, щзо аналіз фінансових результатів діяльності суб'єктів господарювання здійснюється з використанням різних методів $і$ моделей, конкретний вибір яких залежить від иілей та завдань, щчо ставляться. Виділено окремі напрями проведення аналізу фінансових результатів (вертикальний, горизонтальний, трендовий тощо). Встановлено, щуо для повноцінного використання в управлінні результати аналізу фінансових результатів мають відповідати встановленим вимогам. Запропоновано загальну структурно-логічну схему управління фінансовими результатами підприємства та ї̈ аналітичного забезпечення.

Ключові слова: фінансові результати, прибуток, збиток, доходи, витрати, методика аналізу, аналітичне забезпечення, управління.

Kutsyk P.O.,

kutsykpetro@gmail.com,ORCID ID: 0000-0001-5795-9704,

Researcher ID: G-9204-2019

Doctor of Economics, Professor, Rector, Professor of the Department of Accounting, Control, Analysis and Taxation, Lviv University of Trade and Economics, Lviv 


\title{
Herald of Lviv University of Trade and Economics. Economic Sciences. № 62, 2021
}

Voronko R. M., rvoronko@ukr.net, ORCID ID: 0000-0003-3796-2556, Researcher ID: F-8536-2019, Doctor of Economics, Associate Professor, Head of the Department of Accounting, Control, Analysis and Taxation, Lviv University of Trade and Economics, Lviv

Redchenko K. I., redchenko@ukr.net, ORCID ID: 0000-0001-8234-4074, Researcher ID: F-3039-2013, Doctor of Economics, Professor, Professor of the Department of Accounting, Control, Analysis and Taxation, Lviv University of Trade and Economics, Lviv

Voronko O. S., oksanavoronko@i.ua, ORCID ID: 0000-0002-8235-611X, Researcher ID: F-8553-2019, Ph.D., Associate Professor, Associate Professor of the Department of Accounting, Control, Analysis and Taxation, Lviv University of Trade and Economics, Lviv

\section{ANALYTICAL SUPPORT OF MANAGEMENT OF FORMATION OF FINANCIAL RESULTS OF BUSINESS ENTITIES}

\begin{abstract}
The importance of financial performance indicators for assessing the effectiveness of economic entities activity is considered. Economic analysis is defined as a tool for information support of rational management decisions. The tasks of the analysis of financial results directed on revealing of factors of influence on their value, granting of offers on mobilization of the revealed reserves concerning improvement and increase of profitability of activity are defined. Emphasis is placed on problematic issues related to the analysis of financial results and the use of profits, in particular, the information base and methods of its implementation. The economic content of the financial result is defined as the comparison of income obtained with expenses incurred in the reporting period, which causes an increase or decrease in the amount of equity. The financial result characterizes the result (profit or loss) of the business entity activity for a certain period of time. General economic, managerial and accounting-analytical aspects of financial results interpretation are revealed. It is determined that the financial result formed in managerial accounting is focused on possible options for decision-making by managers of different levels, owners, investors or creditors. The analysis of financial results should include not only a detailed assessment of the process of profit formation, but also its use. It is determined that the analysis of financial results of economic entities activities is carried out using different methods and models, the specific choice of which depends on the goals and objectives. Separate areas of analysis of financial results (vertical, horizontal, trend, etc.) are highlighted. It is determined that for full-fledged use in management the financial results analysis must meet the established requirements. The general structural and logical scheme of the enterprise's financial results management and its analytical support is proposed.
\end{abstract}

Key words: financial results, profit, loss, income, expenses, methods of analysis, analytical support, management.

JEL Classification: G31, L26, M41, M42

DOI: https://doi.org/10.36477/2522-1205-2021-62-01

Постановка проблеми. Діяльність суб'єктів господарювання в умовах ринку супроводжується окремими ризиками, що стосуються як безпосередньо неефективності здійснення бізнес-процесів, так і недосконалості інформаційного забезпечення системи управління, зокрема щодо формування фінансових результатів. Важливим засобом інформаційного забезпечення прийняття раціональних управлінських рішень $\epsilon$ економічний аналіз.

У сучасних реаліях визначення економічного змісту фінансових результатів діяльності суб'єкта господарювання, встановлення їх видів, визначення завдань аналізу і розкриття методики його проведення посідають одну 3 основних позицій у комплексному аналізі господарської діяльності. Аналіз фінансових результатів спрямований на пошук резервів покращення фінансового стану суб'єкта бізнесу, інформаційне забезпечення прийняття економічно обгрунтованих рішень за підсумками проведеного оцінювання фінансових можливостей підприємства. Завдання, які вирішуються в процесі такого аналізу, полягають у наступному: встановленні обгрунтованості прогнозу отримання фінансових результатів; оцінюванні показників з формування фінансових результатів і використання прибутку; вивченні динаміки обсягів прибутку та показників рентабельності; виявленні та розрахунку впливу окремих чинників на формування фінансових результатів; пошуку резервів та наданні пропозицій щодо можливостей їх мобілізації для забезпечення зростання прибутковості i рентабельності діяльності.

Проблемні питання аналізу формування фінансових результатів та використання прибутку стосуються інформаційної бази і методики його проведення. Основним інформаційним джерелом для 
аналізу фінансових результатів є бухгалтерська звітність підприємства, зокрема баланс (звіт про фінансовий стан) та звіт про фінансові результати (звіт про сукупний дохід). Потрібно зазначити, що ця звітність $є$ недостатньою для здійснення повноцінного економічного аналізу фінансових результатів, оскільки він повинен забезпечити глибоке дослідження та виявлення рівня впливу на прибуток і рентабельність різних чинників, формулювання обгрунтованих висновків, розробку стратегії зростання доходів та оптимізації витрат діяльності підприємства. Для усунення цих недоліків потрібно удосконалювати структуру фінансової звітності і методику проведення аналізу фінансових результатів, ширше використовувати для цього інтегровану звітність та інформаційну базу управлінського обліку.

Аналіз останніх досліджень і публікацій. Фінансові результати, будучи результативним показником діяльності суб'єктів бізнесу, завжди перебували у сфері наукових досліджень багатьох вченихекономістів. Зокрема, питання аналізу фінансових результатів розкривали у своїх працях такі науковці, як М. С. Білик, Р. Ф. Бруханський, Л. В. Дікань, А. Г. Загородній, Г. І. Кіндрацька, І. В. Кальницька, І. Д. Лазаришина, Є. В. Мних, Л. М. Пилипенко, Н. С. Струк, А. Д. Шеремет, П. М. Яріш та інші. Разом 3 тим, незважаючи на значну кількість наукових досліджень 3 питань аналізу фінансових результатів діяльності суб'єктів господарювання, проблемні питання у даній галузі залишаються та потребують актуальних наукових розробок.

Постановка завдання. Дослідження спрямоване на визначення економічної сутності фінансових результатів діяльності суб'єктів господарювання, розгляд сучасних методик їх аналізу, виявлення основних недоліків та проблем в аналітичному забезпеченні управління результативністю діяльності підприємства і розробку пропозицій з їх вирішення.

Виклад основного матеріалу дослідження. Економічний зміст фінансового результату як показника господарської діяльності за певний період часу полягає у тому, що він виражає приріст або зменшення величини власного капіталу. Розраховується фінансовий результат шляхом співставлення отриманих доходів 3 понесеними витратами звітного періоду. Одержаний результат може мати як позитивне значення (прибуток), яке є доказом ефективного ведення господарської діяльності, або негативне значення (збиток), що вказує на наявність недоліків і прорахунків у діяльності суб'єктів бізнесу. Виявити такі негативні чинники допомагає аналіз фінансових результатів.

Саме такий підхід до визначення фінансового результату прослідковується у працях багатьох науковців і асоціюється 3 категоріями “прибуток" (позитивний результат) або “збиток” (негативний результат). Зокрема, за визначенням авторів фінансово-економічного словника, фінансовий результат - це різниця між доходами та витратами і як приріст або зменшення вартості власного капіталу підприємства [8, с. 623]. Подібний зміст у визначення фінансового результату вкладає Л. І. Есманова, характеризуючи його як різницю між тим, що одержано за виконану роботу, й тим, що фактично витрачено для неї в процесі виробничогосподарської діяльності, 3 метою забезпечення економічної вигоди [3, с. 19].

Інші науковці при визначенні фінансового результату виділяють зміну активних частин його формування (доходу i витрат) i поєднання їх 3 структурними елементами доходу, витрат та власного капіталу, базуючись на елементах облікової політики підприємства, що загалом охоплює усі напрями його діяльності (операційної, фінансової, інвестиційної) i визначає подальший розвиток $[2$, с. 8$]$.

3 метою усунення неоднозначностей у трактуванні категорії “фінансові результати” окремі науковці розглядають іiі у загальноекономічному, управлінському й обліково-аналітичному контекстах $[7$, с. 110]. Перший із них характеризує цю категорію як: кінцевий економічний результат і мотив діяльності; дохід від використання економічних ресурсів; приріст чистих активів; винагороду, котра надається власникам факторів виробництва; зміни у власному капіталі протягом періоду; додану вартість від основної діяльності. Управлінський контекст вбачає у цій категорії: кінцевий результат виробничо-господарської і фінансової діяльності; різницю між маржинальним доходом та постійними витратами; мету господарських операцій і господарської діяльності підприємства. Обліковоаналітичний контекст характеризує фінансові результати як: залишок після здійснення виплати власникам усіх факторів виробництва; різницю між виручкою від реалізації й релевантними витратами; виручку, за виключенням витрат із залучення ресурсів за їх альтернативною вартістю; порівняння доходів та витрат звітного періоду (прибуток, збиток або нульовий результат); обчислення оподатковуваного і нерозподіленого прибутку; інструмент визначення шляхів максимізації прибутку підприємства; основу для оцінювання прибутковості роботи підприємства і його життєздатності.

Фінансовий результат діяльності суб'єкта бізнесу виражає вартісну оцінку завершення чергового етапу його функціонування на ринку продукції (товарів, робіт, послуг). Разом з тим, це також необхідна умова проходження наступного циклу в його розвитку. 3 позиції держави кінцевий фінансовий результат суб'єкта бізнесу розглядається як об'єкт оподаткування податком на прибуток, який у подальшому спрямовується на фінансування виконання державою своїх функцій та різноманітних програм. Власник та інвестор розглядають кінцевий фінансовий результат як частину прибутку після вирахування з нього податку, котра збільшує їхні особисті доходи.

Також, вказуючи на важливість показників фінансових результатів, ми відзначали, що за цими показниками оцінюється ефективність діяльності підприємства: банки вивчають його кредитоспроможність, постачальники та покупці аналізують надійність й платоспроможність як ділового 


\section{Herald of Lviv University of Trade and Economics. Economic Sciences. № 62, 2021}

партнера, інвестори - як об'єкт для потенційного вкладення капіталів [1, с. 250].

Економічна сутність фінансового результату діяльності суб'єктів бізнесу, виходячи 3 порядку його формування у бухгалтерському обліку, полягає у наступному:

1. Фінансовий результат характеризує підсумок діяльності суб' єкта господарювання (прибуток або збиток) за певний період часу, що розраховується як різниця між доходами та витратами від всіх видів його діяльності за вирахуванням суми податку на прибуток.

2. Прибуток суб'єкта господарювання відповідно до стандартів бухгалтерського обліку трактується як різниця між доходами від певної діяльності й витратами на іiі здійснення (позитивна різниця). Такий підсумок характеризує успішне ведення бізнесу.

3. Фінансовий результат належить до вартісних показників, як і всі інші показники, які пов'язані $з$ його розрахунком (отримані доходи та понесені витрати). Разом $з$ тим, фінансовий результат (прибуток чи збиток) є якісним показником діяльності суб'єкта бізнесу, в якому виражається комплексна ефективність усіх видів його діяльності.

4. Прибуток є основним джерелом фінансування сталого розвитку суб'єкта бізнесу, впровадження новітніх технологій у виробничі процеси та реалізації інвестиційних проектів.

Поряд із обліковим підходом до формування фінансового результату, який вимагає чіткого дотримання стандартів бухгалтерського обліку при його обчисленні, може використовуватись інший, варіативний алгоритм його розрахунку, - виходячи 3 потреб менеджменту підприємства, який базується на даних управлінського обліку. Відповідно до першого підходу фінансовий результат, розрахований за вимогами облікових стандартів, знаходить своє відображення у формах фінансової звітності, яка використовується в процесі аналізу та розрахунку показників фінансового стану підприємства. За іншого підходу, який останнім часом набув значної популярності, фінансовий результат формується в управлінському обліку з орієнтацією на можливі варіанти прийняття рішень менеджерами різних рівнів, власниками, інвесторами чи кредиторами. При цьому інформаційне наповнення для аналізу даних про фінансовий результат 3 метою прийняття ефективних рішень формується варіативно залежно від особливостей організації управлінського обліку суб'єкта господарювання.

Інколи науковці характеризують обліковоаналітичну систему як єдине ціле, без виділення у ній облікової, аналітичної і контрольної підсистем $[4$, c. 27$]$.

У міжнародній практиці аналізу фінансових результатів діяльності суб'єктів бізнесу широко використовується проектний аналіз, який зорієнтований на аналіз витрат за пріоритетами їх виникнення в розрізі інвестиційно-інноваційних напрямків, видів, проектів діяльності, котрі мають вагомий вплив на формування кінцевого фінансового результату і тим самим концентрують увагу саме на цих пріоритетах.

Під час здійснення проектного аналізу особлива увага зосереджується на результативності цільового використання фінансових ресурсів, яке передбачає дотримання затвердженого кошторису витрат, цільового використання коштів, своєчасність і повноту освоєння цих ресурсів. Важливе значення при цьому має оцінювання результативності, яке проводиться з використанням відповідної системи комплексних показників результативності.

Величина кінцевого фінансового результату залежить від багатьох чинників: прогнозованість i визначеність зовнішніх і внутрішніх факторів впливу на господарські процеси, конкурентні позиції на ринку товарів (робіт, послуг), зміна обсягів діяльності, порядок формування та використання прибутку, ефективний фінансовий менеджмент та iн.

Аналіз фінансових результатів повинен включати не тільки деталізоване оцінювання процесу формування прибутку, але й також його використання. Аналіз розподілу прибутку на практиці відбувається з використанням відповідної фінансової звітності, показники якої не завжди відображають реальний стан речей і не придатні для проведення повноцінного аналізу через неможливість чіткого розмежування процесу розподілу прибутку між звітними періодами.

Для прикладу, у випадку відвантаження продукції (надання послуг, виконання робіт) на умовах оплати в наступних періодах у пасиві балансу буде відображено прибуток, втілений у заборгованості покупців чи замовників. А це реально завищує фінансову стійкість суб'єкта бізнесу. Також наявність такого прибутку зумовлює потребу сплатити з нього податок та виплатити дивіденди, хоча реальні гроші ще не отримані. Відволікання грошових коштів у дебіторську заборгованість призводить до зниження ліквідності і платоспроможності підприємства, а у випадку не погашення іiі протягом трьох років через погіршення фінансового стану боржника може спричинити незаплановані збитки. Тобто у такій ситуації може статися так, що підприємство $є$ фінансово стійким, але неплатоспроможним.

Окремі науковці також зазначають, що інформаційна база в обліково-аналітичних системах (фінансовій, податковій, управлінській, соціальній й екологічній) генерована таким чином, що певні інформаційні сегменти орієнтовані на конкретні групи користувачів: одні сегменти мають виключно високий рівень публічності, інші - виключно високий рівень конфіденційності [4, с. 27].

Аналіз фінансових результатів діяльності суб'єктів бізнесу здійснюється 3 використанням різноманітних методів і моделей аналізу. Конкретний вибір прийомів і моделей аналізу буде залежати від визначених цілей та завдань. На сьогодні існує певна невизначеність щодо вибору найбільш доцільного методу, який би дозволив провести комплексний аналіз фінансових результатів підприємства та сприяв прийняттю ефективних 
управлінських рішень, спрямованих на удосконалення фінансової політики суб'єкта господарювання, орієнтованої на його стабільний розвиток.

Аналіз фінансових результатів суб'єктів бізнесу повинен бути спрямований на визначення їх складу, динаміки і структури у цілому по підприємству i, що не менш важливо, - за окремими видами діяльності, на що не звертається увага у працях ряду науковців.

Дослідження наукових підходів до проведення аналізу фінансових результатів з метою формування інформаційної бази для управління прибутковістю підприємства дало змогу виділити окремі напрями його проведення. До таких напрямів аналізу фінансових результатів можна віднести: вертикальний, горизонтальний і трендовий; аналіз фінансових результатів у розрізі видів діяльності (операційної, фінансової, інвестиційної) за структурою і динамікою; аналіз факторів, що спричинили зміни показників фінансових результатів; аналіз взаємозв'язку витрат, обсягу діяльності та прибутку; аналіз показників рентабельності; структурнодинамічний аналіз фінансових результатів; коефіцієнтний аналіз фінансових результатів; математико-статистичні методи дослідження фінансових результатів; аналіз резервів збільшення прибутку.

В управлінні фінансовими результатами широкого застосування набув трендовий аналіз, який забезпечує порівняння кожної позиції звітності за звітний і декілька попередніх періодів та визначення тренду, інакше кажучи основної тенденції динаміки показника фінансового результату, очищеної від випадкових впливів чинників зовнішнього та

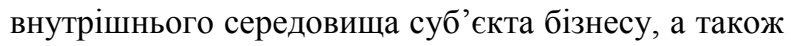
індивідуальних особливостей його діяльності за окремі періоди. Цінність трендового аналізу полягає у тому, що він дає змогу спрогнозувати можливі значення показників фінансових результатів у майбутньому.

П. М. Яріш і Ю. В. Касьянова 3 метою здійснення поглибленого оцінювання фінансових результатів й точнішого обгрунтування рекомендацій, спрямованих на покращення роботи підприємства, рекомендують використовувати CVP-аналіз та концепцію фінансового важеля [9].

Важливе місце у комплексному оцінюванні фінансових результатів діяльності суб'єктів бізнесу має факторний аналіз. Окремі науковці пропонують проводити факторний аналіз прибутку, отриманого від операційної діяльності з використанням адитивної факторної моделі, котра включає узагальнені фактори і дозволяє провести оцінювання впливу кожного із узагальнених факторів (факторів першого порядку) на зміну прибутку від операційної діяльності, а для глибшої деталізації факторного аналізу потрібно розкрити структуру цих факторів за рахунок факторів другого порядку - елементів витрат відповідно до П(С)БО 16 “Витрати" [5, c. 368]:

$\Delta \Pi о=\Delta Ч_{д}-\Delta \mathrm{Cp}+\Delta Д О \mathrm{i}-\Delta \mathrm{Ba}-\Delta \mathrm{B} 3-\Delta \mathrm{BOi}, \quad$ (1) де $\Delta$ По - зміна абсолютної величини прибутку від операційної діяльності підприємства в звітному періоді порівняно з базовим (попереднім або плановим) показником;

$\Delta$ Чд - зміна абсолютної величини чистого доходу;

$\Delta \mathrm{Cp}$ - зміна собівартості реалізованої продукції (товарів, робіт, послуг);

$\triangle Д О і$ - зміна інших операційних доходів;

$\Delta \mathrm{Ba}$ - зміна адміністративних витрат;

$\Delta \mathrm{B}_{3}$ - зміна витрат на збут;

$\triangle \mathrm{BO}$ - зміна інших операційних витрат.

Ми вважаємо, що факторний аналіз фінансових результатів діяльності суб'єктів бізнесу має проводитися не лише за результатами операційної діяльності, але й у межах інших видів діяльності (фінансової та інвестиційної), оскільки їхній результат (прибуток чи збиток) у багатьох випадках має вагомий вплив на загальний фінансовий результат діяльності підприємства.

Окремі науковці пропонують перспективні підвиди аналізу фінансових результатів, які полягають у загальній оцінці досягнутого рівня прибутковості, аналізі структурних змін у формуванні фінансових результатів, аналізі резервів отримання фінансових результатів, аналізі фінансових результатів від акціонерної діяльності та аналізі відносних характеристик прибутковості (збитковості) [6, с. 183].

Аналіз використання прибутку повинен встановити обгрунтованість структури його розподілу за напрямками спрямування у взаємозв'язку з окремими показниками, такими як рентабельність виробництва і продажу, сума прибутку й інвестицій на одного працюючого і на одну гривню вартості основних засобів, коефіцієнт фінансової стійкості і забезпечення власними оборотними активами тощо.

Порядок використання прибутку суб'єкта бізнесу визначає власник. Прибуток підприємства, який підлягає розподілу, використовується на його економічний розвиток (фінансування капітальних інвестицій та інновацій, поповнення власних обігових коштів, збільшення резервного капіталу) та забезпечення соціальних потреб (підвищення кваліфікації працівників, їхнє матеріальне заохочення, розвиток та утримання соціальної інфраструктури). Збитковість суб'єкта бізнесу спричиняють ті самі чинники, котрі визначають його прибутковість.

Для повноцінного використання в управлінні результати аналізу фінансових результатів мають відповідати певним вимогам: об'єктивність (відображення реального стану підприємства); конкретність (використання конкретних фактичних даних, норм і нормативів); точність (проведення точних розрахунків); доступність та зрозумілість (простота і логічність викладення результатів); ефективність (перевищення економічних вигід від результатів аналізу над витратами на його проведення); стислість (результати аналізу повинні бути викладені коротко, без надмірної деталізації); реальність (рекомендації і пропозиції повинні бути придатними для впровадження в умовах даного підприємства 3 наявними ресурсами та можливостями); своєчасність подання (аналітичні результати мають бути надані згідно 3 планами проведення 
аналітичних досліджень); завершеність (вищий ступінь готовності 3 метою використання в практичній діяльності підприємства, для якого проводилося дослідження); конструктивність (сформульовані висновки і рекомендації повинні мати конструктивний характер та описувати конкретні заходи 3 підвищення ефективності господарювання).

Підсистема управління фінансовими результатами підприсмства

(орієнтована на поліпшення фінансових результатів та забезпечення сталого розвитку підприємства)

Управління доходами

- оцінка величини та

складу доходів, рівня достатності для забезпечення прибутковості підприємства;

- формування стратегії отримання доходів за структурними одиницями та ринковими сегментами: - прогноз та оцінка можливостей отримання доходів;

- контроль за виконанням плану отримання доходів
Управління витратами

- планування витрат відповідно до обсягів діяльності; - аналіз обсягу, структури витрат, оцінка факторів, які на них впливають як у цілому, так і за статтями витрат; - економіко-математичне моделювання і прогнозування величини витрат на нові сегменти діяльності;

- контроль відповідності фактичної величини витрат прогнозованій

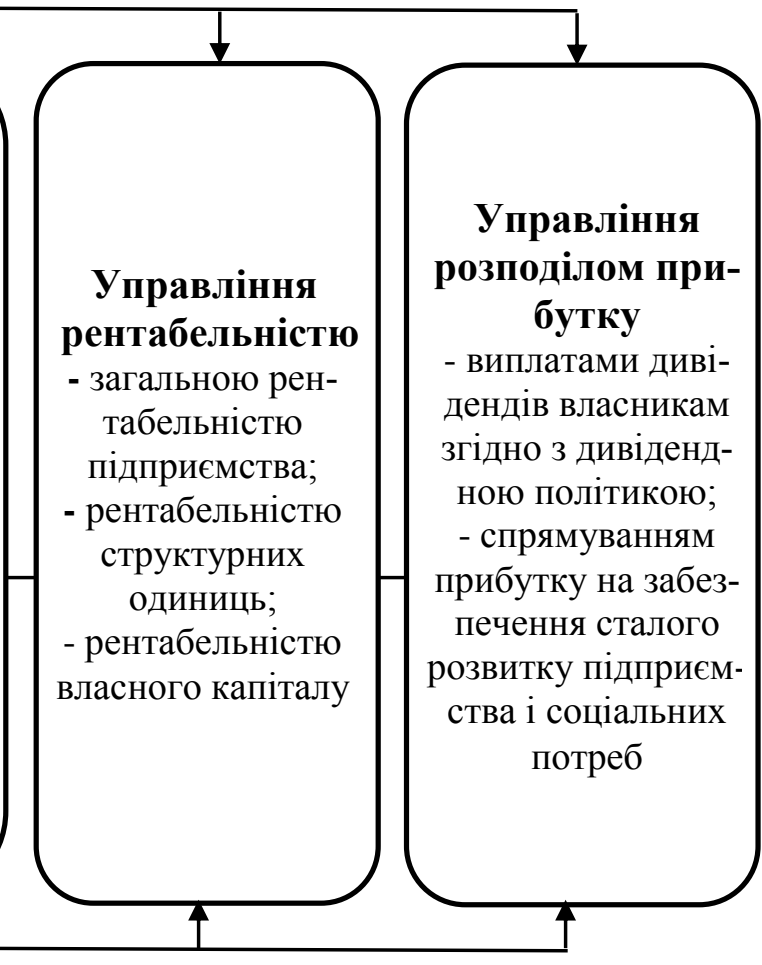

Аналітичне забезпечення управління фінансовими результатами

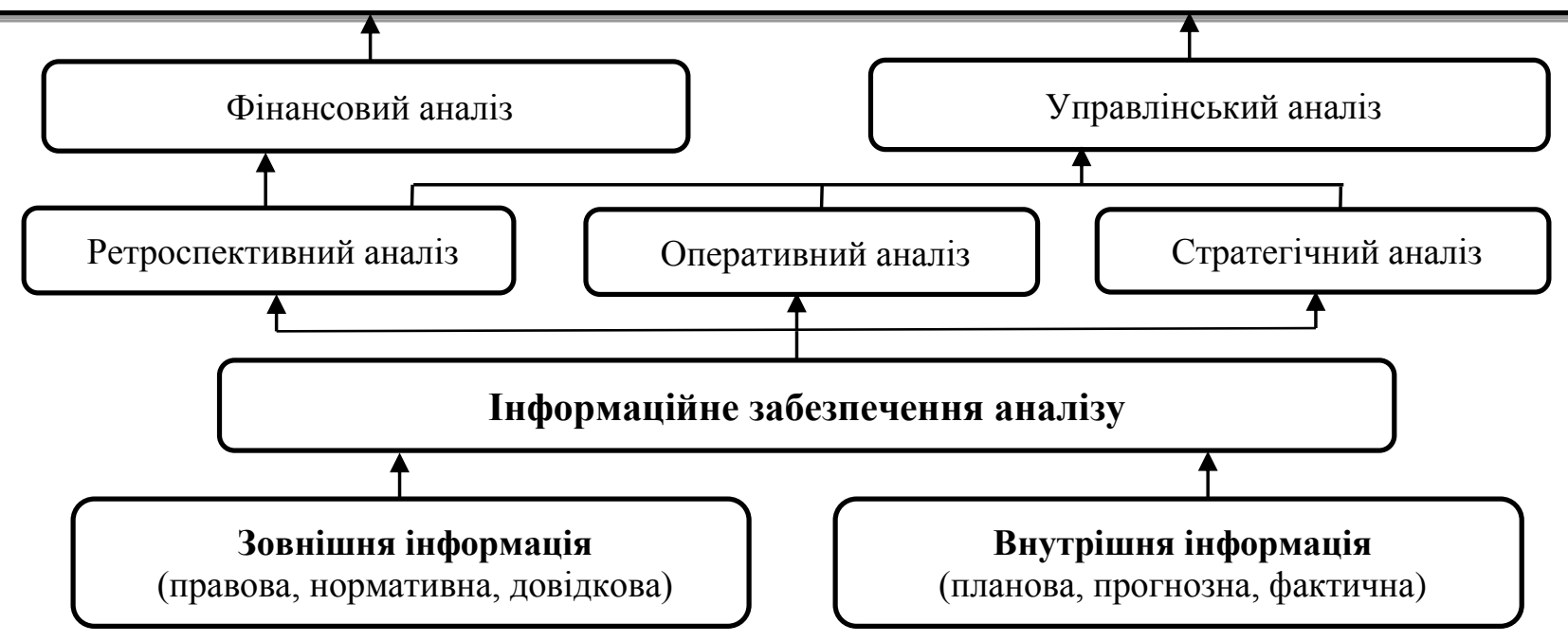

Рис. 1. Підсистема управління фінансовими результатами підприсмства та її аналітичне забезпечення (складено авторами) 
На основі вищевикладеного можна відобразити загальну структурно-логічну схему управління фінансовими результатами підприємства та іï аналітичного забезпечення (рис. 1). Як бачимо, аналітичне забезпечення управління фінансовими результатами може характеризуватися як важливий елемент процесу прийняття управлінських рішень й окрема складова обліково-аналітичної системи підприємства та має включати зазначені функціональні інструменти.

Метою фінансового аналізу, який орієнтується на інформаційне забезпечення управління сталим розвитком суб'єкта господарювання, є виявлення резервів зростання вартості підприємства за одночасного збільшення всіх видів капіталу та неухильного дотримання принципів поступального розвитку.

Відносними показниками, які вказують на ефективність діяльності підприємства, є показники рентабельності. Тому в фінансовому аналізі найважливішими показниками $є$ визначення співвідношення чистого прибутку до обсягів реалізації, величини активів, власного капіталу та витрат. Рентабельність належить до показників, які комплексно характеризують ефективність діяльності і, відповідно, систему управління фінансовими результатами. Для отримання більш повної інформації розраховані показники рентабельності порівнюють за різні періоди та із середньогалузевими значеннями за видами економічної діяльності.

Окремі недоліки фінансового аналізу, які полягають у відсутності оперативності, що не дає змоги швидко оцінити результати діяльності й реальну ситуацію під час їі здійснення, дозволяе компенсувати управлінський аналіз. Управлінський аналіз забезпечує комплексне оцінювання внутрішніх та зовнішніх можливостей підприємства, результати якого спрямовані на встановлення його поточного стану, сильних і слабких сторін, виявлення поточних і стратегічних проблем. Управлінський аналіз має на меті визначення ключових параметрів, котрі забезпечують повну та об'єктивну інформаційну базу, яка використовується для обгрунтування управлінських рішень, спрямованих на досягнення оперативних, тактичних і стратегічних цілей господарської діяльності.

Застосування запропонованої моделі на практиці дозволить суттєво систематизувати роботу, яка стосується планування та управління доходами, витратами та фінансовими результатами суб'єкта господарювання. Основними причинами, які призводять до збиткової діяльності підприємства, є: зменшення обсягів продажу продукції (робіт, послуг), зниження продажних цін, зростання собівартості продукції (робіт, послуг), вимушені простої та тимчасове припинення діяльності, знецінення запасів тощо. Тому організація аналітичного забезпечення управління інформацією, яка містить кількісну та якісну оцінку впливу факторів на зростання прибутку, оптимізацію витрат, а, відповідно, фінансового результату, є одним із першочергових завдань керівництва підприємства.
Висновки i перспективи подалыших досліджень у даному напрямі. Підсумовуючи вищевикладене, можна констатувати, що важливим засобом підвищення ефективності системи управління суб'єктів бізнесу є використання інформаційної бази аналізу фінансових результатів. Економічний зміст фінансового результату проявляється у тому, що він розраховується шляхом співставлення отриманих доходів із понесеними витратами звітного періоду i спричиняє приріст (прибуток) або зменшення (збиток) величини власного капіталу.

Вдосконалення і розвиток методології та процедур здійснення аналізу фінансових результатів (прибутку або збитку) і складових його формування (доходів і витрат), а також прогнозних значень прибутку підприємства забезпечує комплексний аналіз його діяльності, створює можливість визначати тенденції розвитку, фактори впливу на зміни доходів, витрат, показники рентабельності. Це сприятиме пошуку резервів збільшення прибутковості діяльності та прийняттю раціональних управлінських рішень 3 метою підвищення ефективності діяльності та покращення фінансового стану підприємства.

Формування аналітичного забезпечення управління фінансовими результатами діяльності суб'єктів бізнесу залежить від рівня організації та використання методичного інструментарію фінансового й управлінського аналізу для забезпечення прибутковості діяльності підприємства. Перспективним напрямом досліджень $є$ вдосконалення комплексної методики економічного аналізу з урахуванням визначених організаційних та методологічних положень, що дозволить проводити систематичне оцінювання кількісних і якісних показників діяльності суб'єкта бізнесу 3 урахуванням впливу змін у зовнішньому і внутрішньому середовищі на фінансовий стан підприємства.

\section{ЛІТЕРАТУРА}

1. Воронко О. С. Економічний аналіз : навчальний посібник / О. С. Воронко, Н. П. Штепа. - [3-тє вид.]. - Львів : Новий Світ-2000, 2018. - 279 с.

2. Дікань Л. В. Фінансовий результат підприємств: теоретичні узагальнення та прикладний аналіз : монографія / Дікань Л. В. - Х. : СПД Лібуркіна Л. М., 2008. - 92 с.

3. Есманова Л. І. Фінансові результати як економічний інструмент розвитку сільськогосподарських підприємств / Есманова Л. І. - Суми : ВАТ “СОД”, 2007. - 156 с.

4. Кальницкая И. В. Учетно-аналитическое обеспечение управления устойчивым развитием организации / И. В. Кальницкая // Экономический анализ: теория и практика. - 2015. - №17 (416). C. 21-32.

5. Кіндрацька Г. І. Економічний аналіз : підручник / Кіндрацька Г. І., Білик М. С., Загородній А. Г.; [за ред. проф. А. Г. Загороднього]. - [3-тє вид., переробл. та допов.]. - К. : Знання, 2008. $487 \mathrm{c}$.

6. Мних С. В. Фінансовий аналіз : підручник / Є. В. Мних, Н. С. Барабаш. - К. : Київ. нац. торг.екон. ун-т, 2014. - 536 с. 
7. Струк Н. С. Перспективи розвитку методичного підходу до аналізу фінансових результатів на підприємстві / Н. С. Струк, Ю. І. Муц // Науковий вісник Міжнародного гуманітарного університету. Серія : Економіка i менеджмент. - 2017. Вип. 24(2). - С. 109-113 [Електронний ресурс]. Режим доступу: http://nbuv.gov.ua/UJRN/ Nvmgu_eim_2017_24(2)_25.

8. Загородній А.Г. Фінансово-економічний словник / А. Г. Загородній, Г. Л. Вознюк. - [3-тє вид., доп. та перероб.]. - Львів : Видавництво Львівської політехніки, 2011. - 844 с.

9. Яріш П. М. Методи проведення аналізу фінансових результатів діяльності організацій / Яріш П. М., Касьянова Ю. В. // Управління розвитком. - 2015. - № 4 (144). - С. 159-162.

\section{REFERENCES}

1. Voronko, O. S. and Shtepa, N. P. (2018), Ekonomichnyj analiz : navchal'nyj posibnyk, 3 nd ed, Novyj Svit-2000, L'viv.

2. Dikan', L. V. (2008), Finansovyj rezul'tat pidpryiemstv: teoretychni uzahal'nennia ta prykladnyj analiz : monohrafiia, SPD Liburkina L. M., Kh.

3. Esmanova, L. I. (2008), Finansovi rezul'taty iak ekonomichnyj instrument rozvytku sil's'kohospodars'kykh pidpryiemstv, VAT “SOD”, Sumy.
4. Kal'nytskaia, Y. V. (2015), Uchetnoanalytycheskoe obespechenye upravlenyia ustojchyvym razvytyem orhanyzatsyy, Ekonomycheskyj analyz: teoryia y praktyka, No. 17 (416), pp. 21-32.

5. Kindrats'ka, H. I. Bilyk, M. S. and Zahorodnij, A. H. (2008), Ekonomichnyj analiz : pidruchnyk, 3 nd ed, Znannia, Kyiv.

6. Mnykh, Ye. V. and Barabash, N. S. (2014), Finansovyj analiz : pidruchnyk, Kyiv. nats. torh.-ekon. un-t, Kyiv.

7. Struk, N. S. and Muts, Yu. I. (2017), Perspektyvy rozvytku metodychnoho pidkhodu do analizu finansovykh rezul'tativ na pidpryiemstvi, Naukovyj visnyk Mizhnarodnoho humanitarnoho universytetu. Seriia: Ekonomika i menedzhment, vyp. 24(2), pp. 109-113, available at: http://nbuv.gov.ua/ UJRN/Nvmgu_eim_2017_24(2)__25.

8. Zahorodnij, A. H. and Vozniuk, H. L. (2011), Finansovo-ekonomichnyj slovnyk, 3 nd ed, Vydavnytstvo L'vivs'koi politekhniky, L'viv.

9. Yarish, P. M. and Kas'ianova, Yu. V. (2015), Metody provedennia analizu finansovykh rezul'tativ diial'nosti orhanizatsij, Upravlinnia rozvytkom, No. 4 (144), pp. 159-162.

Стаття надійшла до редакиї 03 грудня 2020 p. 